\title{
A CARONA EM VEÍCULOS E SUA INTERMEDIAÇÃO POR APLICATIVOS
}

\author{
CARPOOLING AND ITS INTERMEDIATION BY APPS
}

\author{
Carlos Ari Sundfeld \\ FGV Direito SP (São Paulo, SP, Brasil)
}

André Rosilho

FGV Direito SP (São Paulo, SP, Brasil)

Recebimento: 4 jun. 2019

Aceitação: 20 set. 2019

Como citar este artigo / How to cite this article (informe a data atual de acesso / inform the current date of access):

SUNDFELD, Carlos Ari; ROSILHO, André. A carona em veículos e sua intermediação por aplicativos. Revista da Faculdade de Direito UFPR, Curitiba, PR, Brasil, v. 65, n. 1, p. 59-79, jan./abr. 2020. ISSN 2236-7284. Disponível em: $<$ https://revistas.ufpr.br/direito/article/view/67275>. Acesso em: $30 \quad$ abr. $2020 . \quad$ DOI: http://dx.doi.org/10.5380/rfdufpr.v65i1.67275.

\section{RESUMO}

Neste estudo, inserido em pesquisa doutrinária e legislativa sobre o regime jurídico da economia de compartilhamento no Brasil, será analisada a oferta de carona em veículos particulares, em especial com divisão de custos, e sua intermediação por aplicativos. O objetivo é verificar se há fundamento constitucional para afirmar a liberdade de ofertar e tomar caronas, além de discutir a identidade ou distinção entre prestação de serviço público ou privado de transporte e oferta ou intermediação de caronas, bem como analisar a existência ou não de base legal para regulação pública dos aplicativos de carona. As conclusões do trabalho são que carona é meio de colaboração e associação específica entre cidadãos protegido pelo art. $5^{\circ}$, XVII, da Constituição, que o compartilhamento de custos entre condutores e caronistas não transforma a carona em atividade econômica (serviço de transporte) e que não há lei nacional que autorize a regulação pública dos aplicativos de carona.

\section{PALAVRAS-CHAVE}

Liberdade de associação. Constituição de 1988, art. 5, XVII. Transporte gratuito. Código Civil, arts. 730 e 736.

\begin{abstract}
In this paper, based on doctrinal and legislative research on the legal regime of the sharing economy in Brazil, carpooling in private vehicles, especially with cost sharing, and their mediation by apps is analyzed. It intends to check if there is a constitutional foundation that confirms the freedom to offer and take rides, to discuss the identity or distinction between provision of public and private transport services and the offer or intermediation of carpooling, and to analyze the existence or not of a legal basis for public regulation of carpooling apps. The article's conclusions are that carpooling is a way of collaboration and specific association between citizens, protected by art. 5, XVII, of the Brazilian Federal Constitution, that the sharing of costs between drivers and passengers does not transform
\end{abstract}


carpooling into an economic activity (transportation services) and that there is no national law authorizing the public regulation of carpooling apps.

\section{KEYWORDS}

Freedom of association. Brazilian Constitution of 1988, article 5, XVII. Free transport. Brazilian Civil Code, articles 730 and 736.

\section{INTRODUÇÃO}

Realizadas em moldes tradicionais, viagens por carona são fenômenos pontuais, ocorrem em nichos determinados e de modo esporádico; costumam ser vistas mais como oportunidades do que como alternativa real a serviços de transporte, talvez por isso ainda não tenham suscitado grandes dúvidas jurídicas. Com o desenvolvimento de novas tecnologias, os interessados em ofertar ou tomar caronas têm agora à sua disposição instrumentos mais eficientes de comunicação. Plataformas digitais têm o potencial de mudar significativamente as viagens por carona ${ }^{1}$.

A plataforma é a versão moderna do velho mural da faculdade. Eles têm em comum a mesma função básica: fazer intermediação de caronas, pondo em contato pessoas, conhecidas ou não, que possuam interesses convergentes (colaborar para a realização de viagens para regiões ou locais determinados). Mas se distinguem por ao menos duas diferenças: o universo de oferta e demanda de caronas na plataforma digital é mais amplo (a busca por condutores e caronistas transborda círculos sociais e muros de instituições específicas) e há a possibilidade de caronistas selecionarem condutores a partir de comentários e avaliações deixados na plataforma por outros caronistas.

O que está em jogo pelo ângulo do direito é saber se a carona e os novos meios de facilitála (plataformas digitais de intermediação) são compatíveis com o ordenamento jurídico e se, no regime legal atual, o Estado pode, ou não, regular ou criar óbices à realização dessas atividades. O debate, em seu sentido mais profundo, é sobre a recepção jurídica das novas soluções de economia criativa e colaborativa ${ }^{2}$.

Os tópicos a seguir analisam, a partir das normas constitucionais e legais aplicáveis, se carona é hipótese lícita de associação específica entre cidadãos e se conta com proteção constitucional (item 1); se carona é ou não prestação de serviço de transporte, independentemente do fato de ser ofertada por intermédio de aplicativos e de envolver algum tipo de transferência de recursos (item 2);

\footnotetext{
1 Na elaboração deste estudo os autores contaram com a colaboração dos professores Vera Monteiro e Yasser Gabriel, a quem agradecem.

2 Para uma consistente reflexão jurídica sobre o conceito e as características da economia criativa e colaborativa, ver Siqueira Neto; Menezes (2017).
} 
e se o Estado pode ou não proibir ou regular a oferta de carona, quando feita por plataforma digital (item 3). No tópico final, são resumidas as principais conclusões.

\title{
1 DIREITO DE ASSOCIAÇÃO E AS CARONAS
}

A carona é exemplo de associação lícita e pontual entre cidadãos. Viagens por carona são ajustes para deslocamentos conjuntos, comunhão de esforços entre pessoas (envolvendo bens, recursos, atividades ou prestações) para a consecução de fim comum (realizar deslocamentos para determinados locais ou regiões). A despeito de colaborações desse tipo não se estenderem por longos períodos, também possuem caráter associativo, nos termos abrangentes do art. $5^{\circ}$, XVII, do texto constitucional, segundo o qual “é plena a liberdade de associação para fins lícitos, vedada a de caráter paramilitar” (BRASIL, 1988).

Virgílio Afonso da Silva (2009, p. 92) ressalta a importância das liberdades para a construção do conceito de direitos fundamentais:

\begin{abstract}
A análise histórica aponta que o primeiro tipo de direito reconhecido como fundamental são as liberdades. Estas são os direitos subjetivos de agir segundo a própria vontade, sem impedimento por parte de quem quer que seja. Nada reclama do sujeito passivo, senão a nãooposição. Poderiam ser resumidos num só: o direito à liberdade pessoal, como autodeterminação da conduta.
\end{abstract}

Seguindo nessa linha, a Constituição de 1988 conferiu especial proteção às liberdades, tanto em sua dimensão individual como coletiva. Ao inserir amplo conjunto de liberdades no rol dos direitos fundamentais - caracterizados como cláusula pétrea pelo art. 60, § $4^{\circ}$, IV - a Constituição quis incentivar amplamente a ação individual e coletiva dos membros da sociedade, e também criar importantes barreiras às ingerências do Estado na vida privada.

Em esforço de classificação, José Afonso da Silva (2005, p. 70) afirma que estariam resguardadas pelo direito constitucional positivo, sobretudo pelo que dispõem o caput e os incisos do art. 5", a "liberdade da pessoa física (liberdades de locomoção e de circulação)"; a "liberdade de pensamento (opinião, religião, informação, artística, comunicação do conhecimento)"; a "liberdade de expressão coletiva (de reunião, de associação)"; a "liberdade de ação profissional (de escolha e exercício de trabalho, ofício e profissão)"; e a "liberdade de conteúdo econômico e social (livre iniciativa, liberdade de comércio, liberdade ou autonomia contratual, liberdade de ensino e liberdade de trabalho)". Trata-se de um conjunto bastante abrangente de proteções em favor do desenvolvimento da criatividade social. 
As experiências de união de indivíduos são quase inclassificáveis, tendo em conta a riqueza da vida social contemporânea. Portanto, a carona é apenas mais um caso de associação lícita, sem fins lucrativos, para fins específicos. Segundo Schor (2017, p. 28), outros exemplos da economia de compartilhamento no mundo contemporâneo seriam as "bibliotecas de ferramentas, [os] bancos de sementes, [os] bancos de tempo, e as trocas de alimentos”. Nesses exemplos, segundo a autora, os indivíduos não estão em busca de lucro, mas sim, como nas caronas, de atender a necessidades em escala comunitária, por meio de associações específicas, que não envolvem a constituição de pessoa jurídica associativa.

Interessa ao presente estudo uma dessas liberdades: a de “associação para fins lícitos” (art. 5 XVII, da Constituição), que se presta "a satisfazer necessidades várias dos indivíduos, aparecendo, ao constitucionalismo atual, como básica para o Estado Democrático de Direito” (MENDES; COELHO; BRANCO, 2009, p. 444) ${ }^{3}$. A oferta e aceitação de carona se inserem justamente nessa específica forma de liberdade constitucional da expressão coletiva, que não se limita às palavras, abrangendo também as ações. Em sentido amplo, dela decorre o direito de os cidadãos se unirem para a realização de objetivos comuns, inclusive por meio do compartilhamento de bens, recursos, atividades ou prestações. É o direito de base constitucional de as pessoas privadas cooperarem para fins lícitos de interesse mútuo.

A doutrina, ao comentar em abstrato a liberdade de associação, normalmente o faz mirando a criação de pessoas jurídicas, de entidades associativas e cooperativas, o que é tema específico de outro preceito, o do inciso XVIII do mesmo art. $5^{\circ}$ da Constituição ${ }^{4}$ (ACCIOLY, 2016; SILVA, 2005). Mas a verdade é que o direito constitucional de as pessoas se unirem e de compartilharem, cuja origem está na garantia da liberdade de associação - uma garantia mais ampla, objeto do outro dispositivo, o inciso XVII do art. $5^{\circ}$ da Constituição -, não se traduz apenas no direito de criar pessoas jurídicas. Envolve também outras experiências comunitárias, inclusive o direito de realizar colaborações específicas de caráter não lucrativo -; isto é, colaborações eventuais entre cidadãos, sem caráter duradouro, desprovidas de ânimo permanente. Nisso se inclui a carona.

Não se pode interpretar de modo restritivo ou anacrônico a liberdade do inciso XVII do art. 5. Em comentário sobre liberdades públicas, Robert (1993, p. 733-734, tradução nossa) explica que

3 A ideia-chave é descrita por Branco (MENDES; COELHO; BRANCO, 2009, p. 444): “Quando não podem obter os bens da vida que desejam, por si mesmo [sic], os homens somam esforços, e a associação é a fórmula para tanto. Associando-se com outros [voluntariamente, para fins lícitos de cunho comercial ou não comercial], promove-se maior compreensão recíproca, amizade e cooperação, além de se expandirem as potencialidades de autoexpressão”.

4 “Art. 5 XVIII - a criação de associações e, na forma da lei, a de cooperativas independem de autorização, sendo vedada a interferência estatal em seu funcionamento”. 
a cooperação entre indivíduos para tarefas mais ou menos amplas é da essência da própria democracia. Segundo o autor:

\begin{abstract}
Associar-se corresponde a uma necessidade de fazer algo em conjunto, ou de se defender de algo em conjunto. Essa necessidade é mais presente quanto mais afastado for o poder político e mais complexa for a sociedade. [...] A associação, em princípio, envolve conexão. Na sua essência, o poder do grupo, em vez de oprimir, gera proteção. No domínio da cultura, do turismo, do lazer, o desenvolvimento do indivíduo frequentemente passa pela realização de atividades em grupo; a associação preenche, assim, uma função social relevante. [...] Escolas da democracia e garantes da liberdade, as associações podem, enfim, contribuir para conferir à sociedade a solidez que lhe falta. Uma sociedade resiste melhor a tempestades quando sua população se sente responsável pela vida cotidiana [o autor cita Lenoir (1976)]. A solidariedade deve ser vivida ativamente. Ela não deve ser desencorajada.
\end{abstract}

O associativismo político clássico, envolvendo valores fundamentais como as liberdades de reunião, de expressão do pensamento, de proselitismo político, de participação eleitoral, etc., vinculase à temática dos direitos políticos. Já o associativismo econômico vincula-se a um só tempo aos direitos individuais (associativismo como forma de liberdade econômica) e aos direitos sociais (associativismo econômico como solução de desenvolvimento social).

A face mais conhecida do associativismo econômico é a formação de empresas e de cooperativas, as quais, de modos diferentes, permitem a racionalização das atividades econômicas, por meio de sua exploração em conjunto e com objetivo de lucro. Ao presente estudo interessa destacar que a tecnologia tem potencializado outra face do associativismo econômico: a associação para a geração de valor por meio do compartilhamento eficiente de meios escassos entre sujeitos, sem o objetivo imediato de explorar atividade econômica; trata-se de racionalização econômica coletiva, não exatamente de atividade econômica coletiva.

Uma visão democrática e contemporânea das formas de associação protegidas constitucionalmente tem de incluir as crescentes soluções propiciadas pela tecnologia para o compartilhamento de meios entre cidadãos, valorizando a conexão ativa e direta entre eles. As pessoas que ampliam sua capacidade e sua disponibilidade para a união e para o compartilhamento de refeições, de imóveis, de veículos, de trabalho, etc., experimentam nova dimensão da cidadania e também se tornam mais sensíveis à responsabilidade coletiva pela sustentabilidade.

O associativismo que a Constituição abriga, valoriza e protege não pode ser limitado a modelos de organização social do passado. Tem de considerar o novo paradigma, a economia criativa e colaborativa, que "surge no cenário da desmaterialização das relações de trabalho e de formação de uma economia baseada na informação e conhecimento, bem como em um contexto de alta dinamização da cultura de consumo e de estilo de vida alternativos ao modelo fordista [...]”, envolvendo "organização dos mercados em redes, alianças entre agentes econômicos e sociais, a 
prevalência de aspectos intangíveis da produção [...]”, entre outras características que podem "melhorar o bem-estar e a inclusão econômica, superando assim o chamado 'paradigma da chaminé’” (SIQUEIRA NETO; MENEZES, 2017, p. 65).

Com o desenvolvimento de aplicativos, que facilitam de modo impressionante a conexão entre indivíduos, as caronas podem se tornar uma solução amplamente utilizada para o compartilhamento de meios de deslocamento. Assim, é possível que se esteja no início de uma nova era, em que a mobilidade tenderá a se tornar menos dependente das soluções individuais, por um lado, e dos serviços de transporte de massa, por outro, passando a contar com um segmento relevante de transporte por compartilhamento, de que serão parte as caronas.

A Constituição, no inciso XV do art. 50, diz ser "livre a locomoção no território nacional em tempo de paz, podendo qualquer pessoa, nos limites da lei, nele entrar, permanecer ou dele sair com seus bens” (BRASIL, 1988, grifo nosso). A liberdade constitucional quanto às formas de locomoção de interesse de cada pessoa também tem impacto na compreensão da carona como alternativa lícita. O Estado não pode coibi-la sem que ponha em risco tal liberdade. É preciso, então, conhecer melhor esse campo. Qual a especificidade da carona como solução de transporte?

A carona não se desnatura, tampouco perde seu caráter associativo, ao assumir formas variadas - revezamento quanto ao veículo ou ao condutor, divisão simétrica ou assimétrica de despesas, etc. E é natural que, em caronas, os envolvidos busquem benefícios de parte a parte imateriais (oportunidade para a convivência humana) ou materiais (economia de esforços pelo revezamento na condução; economia de recursos pelo compartilhamento de meios ou divisão de custos, etc.).

É possível, por exemplo, que algum viajante, visando reduzir o risco de adormecer ao volante em deslocamento noturno, ofereça carona para trajeto específico; aqui, o benefício do condutor é apenas imaterial (segurança, tranquilidade). Também é viável o arranjo entre amigos por meio do qual caronistas se responsabilizam pelo custeio de parte das despesas com o trajeto (por exemplo, gastos com combustível); o benefício do condutor, nesse caso, é imaterial (convívio com terceiros) e material (redução de custos com a viagem). No exemplo, apesar de dividir certas despesas com caronistas, o condutor não recupera mais do que seus custos (e, por isso, não aufere lucro).

A despeito de os benefícios do condutor num caso e noutro terem naturezas distintas, ambos são exemplos de viagens por carona. Esse tipo de ajuste, preservadas certas características essenciais (às quais se referirá no tópico subsequente), admite diferentes arranjos e combinações, todos eles protegidos pela liberdade constitucional de associação. 


\section{CARONAS E SERVIÇOS DE TRANSPORTE}

A prestação de serviço de transporte supõe contraposição de interesses e de prestações entre o transportador, que o realiza em caráter profissional, para obter lucro, e a pessoa transportada, que versa remuneração correspondente à prestação que obtém, e tem direito ao serviço ${ }^{5}$. A carona, por sua vez, supõe identidade de interesses, tanto de quem a dá como de quem a toma: ambos têm efetiva necessidade ou desejo pessoal de se deslocar para destino comum. Coelho (2017, p. 412) faz destaque útil para distinguir entre carona e serviço de transporte: esse último envolve prestação "no interesse da outra parte (contratante do serviço)”. Explica o autor:

Dois requisitos são essenciais para a configuração do contrato de transporte: a empresarialidade do transportador e a onerosidade. Se quem leva pessoa ou coisa para outro lugar no interesse alheio não faz disso sua atividade econômica organizada ou o faz graciosamente, a relação jurídica não é a de contrato de transporte. Rege-se pelas regras gerais das obrigações de fazer e dos contratos gratuitos.

O condutor, nesse caso, não dirige por ofício ou profissão - e, por conseguinte, não visa ao lucro. Essa é a razão pela qual não existe, nem poderia existir, licença especial para o condutor que oferta caronas. Ele está sujeito às regras de trânsito que se aplicam à generalidade dos motoristas privados, que usam veículos para transporte não profissional. Sua decisão de realizar determinado trajeto não tem origem em solicitação de passageiro, antes ao contrário; é o passageiro que, sabendo do destino do condutor, se junta a ele, com seu prévio consentimento, para executar plano de viagem comum.

Na carona não há prestação e contraprestação, mas concurso entre os envolvidos, que assumem o transporte como atividade conjunta, mesmo que cada envolvido participe com ações diferentes. A carona está para a prestação de serviços como a noção clássica de convênios está para os contratos públicos ${ }^{6}$.

A obtenção de simples benefício pelos envolvidos na carona - mesmo econômico, por meio de compartilhamento dos custos - não é suficiente para caracterizá-la como atividade econômica. O serviço de transporte, atividade econômica, supõe, por um lado, o transporte como ofício ou profissão, e, por outro, objetivo lucrativo, evidenciado pela cobrança de preço, remuneração em sentido próprio.

\footnotetext{
5 A prestação do serviço de transporte pressupõe a figura do transportador profissional. Aquele que presta serviço de transporte de modo amador - isto é, visando ao lucro, mas sem licença prévia - realiza transporte irregular, nos termos do art. 231, VIII, do Código de Trânsito Brasileiro (BRASIL, 1997, grifo nosso), que define como infração "transitar com o veículo: [...] efetuando transporte remunerado de pessoas ou bens, quando não for licenciado para esse fim, salvo casos de força maior ou com permissão da autoridade competente”.

6 Para a distinção, ver Meirelles (2012, p. 458).
} 
A Lei 12.587/2012 (Lei da Política Nacional de Mobilidade Urbana) (BRASIL, 2012), por exemplo, ao traçar diretrizes para a regulação dos serviços de transporte público coletivo em âmbito nacional, define que a tarifa tem de ser constituída pelo preço público cobrado do usuário, de forma a cobrir os reais custos do serviço, além da remuneração do prestador. Veja-se:

Art. $9^{\circ} \mathrm{O}$ regime econômico e financeiro da concessão e o da permissão do serviço de transporte público coletivo serão estabelecidos no respectivo edital de licitação, sendo a tarifa de remuneração da prestação de serviço de transporte público coletivo resultante do processo licitatório da outorga do poder público.

$\S 1^{\circ}$ A tarifa de remuneração da prestação do serviço de transporte público coletivo deverá ser constituída pelo preço público cobrado do usuário pelos serviços somado à receita oriunda de outras fontes de custeio, de forma a cobrir os reais custos do serviço prestado ao usuário por operador público ou privado, além da remuneração do prestador.

A referida política nacional de mobilidade urbana de que trata a Lei 12.587/2012 não se aplica às caronas, que não são serviços de transporte. Ela surgiu da atribuição, prevista no art. 21, XX, da Constituição de 1988, para a instituição, pela União, de “diretrizes para o desenvolvimento urbano” relativas aos "transportes urbanos”, combinada com sua competência legislativa privativa em matéria de “transporte”, prevista no art. 22, XI, da Constituição. A lei nacional passou a trazer diretrizes, até então inexistentes em âmbito nacional, para pautar as competências locais (municipais) sobre os serviços de transporte urbano (nas modalidades coletivo e individual).

A novidade foi a de haver garantido, por norma nacional (art. $3^{\circ}$, $\S 2^{\circ}$, III, $\mathrm{b}^{7}$; art. $4^{\circ}$, $\mathrm{X}^{8}$; e art. $11-\mathrm{A}^{9}$ e $11-\mathrm{B}^{10}$, todos da Lei $\left.12.587 / 2012\right)$, a abertura, ao serviço privado, do mercado de transporte remunerado individual de passageiros, limitando as medidas que, no passado, foram usadas pelos municípios para restringir aos táxis o mercado de transporte remunerado individual de passageiros. O art. 4 X (cuja redação atual foi dada pela Lei 13.640/2018) (BRASIL, 2018), reconheceu a existência do "transporte remunerado privado individual de passageiros”, definindo-o como “serviço remunerado de transporte de passageiros, não aberto ao público, para a realização de

7 “Art. $3^{\circ}$ O Sistema Nacional de Mobilidade Urbana é o conjunto organizado e coordenado dos modos de transporte, de serviços e de infraestruturas que garante os deslocamentos de pessoas e cargas no território do Município. [...] $\S$ $2^{\circ}$ Os serviços de transporte urbano são classificados: [...] III - quanto à natureza do serviço: [...] b) privado” (grifo nosso).

8 “Art. $4^{\circ}$ Para os fins desta Lei, considera-se: [...] X - transporte remunerado privado individual de passageiros: serviço remunerado de transporte de passageiros, não aberto ao público, para a realização de viagens individualizadas ou compartilhadas solicitadas exclusivamente por usuários previamente cadastrados em aplicativos ou outras plataformas de comunicação em rede" (grifo nosso).

9 “Art. 11-A. Compete exclusivamente aos Municípios e ao Distrito Federal regulamentar e fiscalizar o serviço de transporte remunerado privado individual de passageiros previsto no inciso $\mathrm{X}$ do art. $4^{\circ}$ desta Lei no âmbito dos seus territórios” (grifo nosso).

10 “Art. 11-B. O serviço de transporte remunerado privado individual de passageiros previsto no inciso X do art. $4^{\circ}$ desta Lei, nos Municípios que optarem pela sua regulamentação, somente será autorizado ao motorista que cumprir as seguintes condições: [...]” (grifo nosso). 
viagens individualizadas ou compartilhadas solicitadas exclusivamente por usuários previamente cadastrados em aplicativos ou outras plataformas de comunicação em rede”. A Política Nacional de Mobilidade Urbana, portanto, assegurou a existência de serviço de transporte individual remunerado de passageiro, garantindo a sua convivência com os taxistas (o que, até então, era altamente conflituoso).

Essa política nacional de mobilidade urbana não interfere nas caronas, nem em sua intermediação digital pois: (a) o objeto da regulação legal é apenas o serviço de transporte urbano; (b) quem oferece carona não presta esse serviço; e, ainda, (c) a operação de plataforma digital de intermediação de caronas também não se confunde com prestação de serviço de transporte.

Conforme o dispositivo supracitado (art. $9^{\circ}$, § $1^{\circ}$, da Lei 12.587/2012), a prestação do serviço de transporte público coletivo deve ser retribuída pelo pagamento de tarifa, isto é, por um preço. Como visto, o preço é a somatória de duas partes: uma capaz de cobrir os efetivos custos do serviço e outra para remunerar seu prestador, proporcionando-lhe lucro. Nas caronas, mesmo quando haja divisão de custos, não há preço, pois está ausente a outra parte: a remuneração lucrativa de quem propicia o transporte.

Em respeito às liberdades constitucionais, o Código Civil (BRASIL, 2002), ao disciplinar o transporte, previu, por um lado, o transporte mediante “retribuição”, modalidade de atividade econômica lucrativa objeto do contrato de transporte (art. 730), e, por outro, a carona, o transporte feito "gratuitamente”, sem finalidade lucrativa direta ou indireta, o qual é livre e tem regime jurídico distinto do contrato de transporte, em aspectos obrigacionais e de responsabilidade (art. 736) ${ }^{11}$. Confira-se:

Art. 730. Pelo contrato de transporte alguém se obriga, mediante retribuição, a transportar, de um lugar para outro, pessoas ou coisas.

[...]

Art. 736. Não se subordina às normas do contrato de transporte o feito gratuitamente, por amizade ou cortesia.

Parágrafo único. Não se considera gratuito o transporte quando, embora feito sem remuneração, o transportador auferir vantagens indiretas.

As normas do Código Civil aludem a transporte "mediante retribuição" ou "feito gratuitamente”, mas não conceituam "retribuição" e "gratuidade"12. Todavia, nem toda transferência

11 Sobre o tema da responsabilidade em caronas, por exemplo, a Súmula 145 do STJ (BRASIL, 1995) diz o seguinte: "No transporte desinteressado, de simples cortesia, o transportador só será civilmente responsável por danos causados ao transportado quando incorrer em dolo ou culpa grave”.

12 A mesma técnica legislativa é empregada pelo Código Civil (BRASIL, 2002), por exemplo, com relação ao mandato, que, mediante o art. 658, presume-se "gratuito quando não houver sido estipulada retribuição, exceto se o seu objeto corresponder ao daquele que o mandatário trata por ofício ou profissão lucrativa”. 
de valores, bens ou serviços, feita a quem oferece carona, pode ser classificada como retribuição pela atividade de transporte realizada, a qual supõe que os valores não só cubram os custos proporcionais, imediatos e mediatos, como gerem excedente apropriável (lucro), equiparando-se assim ao "preço" dos serviços profissionais de transporte equivalentes.

Seria inadequado classificar como retribuição o dinheiro que algum condutor receba de caronistas para reembolso de despesas normais de viagem realizada em conjunto - por exemplo, com combustível e pedágios. Esses valores são transferidos ao condutor não para remunerá-lo, mas para compensar custos. Falta a esses valores ingrediente essencial para serem rotulados como retribuição: o lucro.

Nem toda transferência de valores, bens e serviços pela realização de atividade é retribuição. A legislação reconhece que essa se compõe de dois elementos: por um lado, compensação por custos, por outro, excedente apropriável (lucro ou remuneração) $)^{13}$.

A lógica de que nem toda transferência de valores é retribuição também está presente em outros nichos da vida cotidiana. Outro exemplo é o comodato, definido pelo art. 579 do Código Civil como "empréstimo gratuito de coisas não fungíveis" (BRASIL, 2002). A despeito de a lei falar em gratuidade, seria equívoco imaginar que o empréstimo gratuito a outrem de uma coisa não fungível suporia a total ausência de desembolso pelo comodatário. No caso de empréstimo gratuito de um apartamento, por exemplo, é viável que, sem descaracterizar o comodato, comodante e comodatário acordem que esse, em nome daquele, adimpla obrigações tributárias e condominiais atreladas ao imóvel.

Ao concordar, por exemplo, com o pagamento de IPTU e de despesas de condomínio em nome do comodante, o comodatário não está aquiescendo com empréstimo oneroso. Trata-se da assunção de custos inerentes à existência mesma do imóvel objeto de empréstimo. Mas a situação será outra se, por exemplo, o morador combinar com o proprietário que, além de arcar com as despesas normais do imóvel (IPTU e condomínio), versará, em favor deste, valor adicional para remunerar o uso. Aí sim haverá descaracterização do comodato, que se converterá, mesmo informalmente, em locação de imóvel. Essa parcela adicional de valor corresponderia à remuneração do proprietário, ao preço - que, tratando-se de locação de imóveis, tem o nome de aluguel. O sujeito que cobra aluguel faz uso econômico de sua propriedade. Visa não apenas se desfazer das despesas

\footnotetext{
13 Esse sistema normativo tem de ser considerado na aplicação do art. 231, VIII, do Código de Trânsito Brasileiro, que considera infração de trânsito o "transporte remunerado de pessoas e bens" quando o sujeito "não for licenciado para esse fim” (BRASIL, 1997). A carona, ainda que envolva reembolso de despesas, não é transporte remunerado, não é prestação de serviços, de modo que não exige licença administrativa.
} 
normais e inerentes a um imóvel (IPTU e condomínio, no caso de apartamentos), mas receber do locatário uma remuneração (lucro) pelo seu uso.

Percebe-se, assim, que os elementos conceituais adotados, tanto pela legislação setorial sobre serviços de transporte, como pelo art. 736 do Código Civil, são suficientes para afastar a confusão entre os serviços de transporte e a atividade de oferecer e tomar caronas.

Vale, neste ponto, uma última palavra sobre o parágrafo único do art. 736 do Código Civil, que considera como não gratuito o transporte que, embora feito sem cobrança de preço específico, gere “vantagens indiretas” para o transportador. Na aplicação desse dispositivo, tem-se entendido tais vantagens indiretas como as de outra atividade econômica explorada de modo conexo pelo próprio transportador, como nos casos de traslado oferecido por hotéis, restaurantes, lojas, clínicas, faculdades privadas, etc., cujos preços embutem a remuneração também pelo transporte ${ }^{14}$. $\mathrm{O}$ motorista que, em nome do hotel, busca hóspede no aeroporto “de graça”, de fato não o faz a título gratuito. Ainda que o transportado não lhe pague diretamente, o serviço é remunerado pela atividade do hotel - que embute o valor desse preço nas tarifas pagas pelo hóspede. As vantagens indiretas do transportador (neste caso, o hotel) são evidentes. Por isso faz sentido não considerar gratuito (carona) o transporte que, embora feito sem a cobrança, ao transportado, de preço específico, gere vantagens indiretas ao transportador. Essa é a leitura que a doutrina faz do parágrafo único do art. 736 do Código Civil. Segundo Coelho (2017, p. 412):

Não é indispensável a remuneração direta pelos serviços de transporte para desfigurar-se a
gratuidade. Também é oneroso o contrato em que o transportador nada cobra diretamente em
função do deslocamento, mas aufere vantagens indiretas (art. 736, parágrafo único). Quando
o shopping center disponibiliza a qualquer interessado transporte por micro-ônibus entre o
ponto de sua localização e alguns próximos, e o faz sem cobrar nenhum pagamento pelo
serviço, o contrato aqui não se considera gratuito porque o transportador tem a vantagem
indireta de facilitar a ida de mais consumidores ao centro de compras - objetivo perseguido
ao disponibilizar a comodidade.

Não se pode, para fins de caracterização de uma solução de transporte compartilhado como se fosse serviço remunerado de transporte, na forma desse parágrafo do art. 736 do Código Civil, considerar como vantagem indireta o recebimento de simples reembolso de despesas. Reembolso não é remuneração, não se caracteriza como vantagem de quem oferece a carona.

Usando linguagem comum, o art. 736 do Código Civil se referiu à “amizade ou cortesia” como razões da carona. O objetivo foi marcar o caráter não profissional desse transporte, por não envolver a reiteração e o volume típicos do ofício de transportador. O simples compartilhamento dos

14 Ilustra o sentido do art. 736 do Código Civil "o caso do dono de hotel que transporta gratuitamente seus hóspedes ao aeroporto” (NEGRÃO; GOUVÊA; BONDIOLI, 2010, p. 236). 
custos é compatível com a cortesia e é normal nas atividades associativas; não compromete a gratuidade e, por isso, não descaracteriza a carona.

O advento da internet, em específico o das redes sociais, ampliou as possibilidades de transporte por “amizade ou cortesia”. Novas ferramentas de comunicação alargaram os círculos sociais, viabilizando o contato direto entre pessoas que, apesar de se conhecerem, não convivem (ou não se veem com frequência) fora do ambiente virtual. As redes permitiram que as relações de proximidade humana (por afinidade) se multiplicassem. E o fato de mais seres humanos estarem em contato uns com os outros por relações de afinidade favorece o desenvolvimento de atividades associativas - entre as quais, a carona.

A conclusão deste item é, portanto, que a legislação nacional, em aplicação concreta da ampla liberdade de associação garantida constitucionalmente, reconhece a carona como solução lícita de transporte compartilhado, além de conter elementos importantes para distingui-la das atividades econômicas, isto é, dos serviços públicos e privados de transporte.

Isso remete ao outro aspecto: a discussão quanto à possível relação entre as operações privadas que compõem as experiências mais atuais de caronas por meio de aplicativos (a atividade de ofertá-la e de tomá-la, por um lado, e a atividade tecnológica de conexão entre ofertante e tomador, por outro) e as competências das autoridades administrativas reguladoras dos serviços de transporte.

\section{CARONA E REGULAÇÃO ESTATAL}

Cabe ao poder público fazer a regulação e a outorga dos serviços públicos de transporte (art. 175 da Constituição ${ }^{15}$ ) e também, observados os limites constitucionais da liberdade econômica, a regulação dos serviços privados de transporte (arts. $170^{16}, 174^{17}$ e $178^{18}$, da Constituição). Mas as autoridades não podem coibir ou regular as caronas, que não são prestação de serviço remunerado,

\footnotetext{
15 “Art. 175. Incumbe ao Poder Público, na forma da lei, diretamente ou sob regime de concessão ou permissão, sempre através de licitação, a prestação de serviços públicos” (BRASIL, 1988).

16 “Art. 170. A ordem econômica, fundada na valorização do trabalho humano e na livre iniciativa, tem por fim assegurar a todos existência digna, conforme os ditames da justiça social, observados os seguintes princípios: [...] Parágrafo único. É assegurado a todos o livre exercício de qualquer atividade econômica, independentemente de autorização de órgãos públicos, salvo nos casos previstos em lei” (BRASIL, 1988, grifo nosso).

17 “Art. 174. Como agente normativo e regulador da atividade econômica, o Estado exercerá, na forma da lei, as funções de fiscalização, incentivo e planejamento, sendo este determinante para o setor público e indicativo para o setor privado" (BRASIL, 1988, grifo nosso).

18 “Art. 178. A lei disporá sobre a ordenação dos transportes aéreo, aquático e terrestre, devendo, quanto à ordenação do transporte internacional, observar os acordos firmados pela União, atendido o princípio da reciprocidade” (BRASIL, 1988, grifo nosso).
} 
público ou privado, mas meio de colaboração e associação específica entre cidadãos (atividade privada, lícita e livre).

Experiência recente é o surgimento das plataformas digitais de intermediação de caronas $^{19}$. As operadoras dessas plataformas não realizam transporte, limitando-se a facilitar a comunicação entre pessoas interessadas em dar e em tomá-las. Prestam serviço de aproximação, que não se confunde com a atividade de carona em si. Funcionam como ambiente (não físico, virtual) em que condutores dão visibilidade à intenção de ofertar caronas e caronistas dão visibilidade à sua intenção de tomá-las. Limitam-se a veicular informações entre pessoas, pondo-as em contato, ampliando as possibilidades de associação para atividade específica (carona).

Essas operadoras não "vendem” caronas. Vendem serviço facilitador e a oportunidade de interessados em tomar caronas identificarem, por meio de acesso a esse ambiente, condutores dispostos a ofertá-las para determinado local ou região. O valor que recebem de seus usuários é pela prestação desse serviço informacional, voltado à aproximação de pessoas específicas com interesses convergentes ${ }^{20}$.

Em muitos aspectos, esse serviço é similar ao que os jornais impressos prestam por meio de seus “classificados”, que são plataformas (físicas) que veiculam informações, facilitando o contato entre sujeitos com interesses convergentes (pessoas que desejam comprar e vender carros ou imóveis; empregadores em busca de funcionários e pessoas em busca de emprego, etc.). A principal diferença da plataforma digital é que ela põe em contato direto sujeitos individualizados, específicos, enquanto os tradicionais “classificados” se limitam a divulgar informações às massas, às pessoas em geral.

Há diversos exemplos de plataformas digitais que prestam serviço de aproximação, facilitando a realização de atividades diversas - Tinder para relacionamentos; Singu para serviços de salão de beleza; e Bicos para serviços gerais domésticos. Em nenhum caso, a atividade de

19 BlaBlaCar e Waze Carpool são plataformas de intermediação que atualmente fornecem serviços para viabilizar a carona compartilhada (transporte sem finalidade lucrativa, com divisão dos custos da viagem). Diferenciam-se das plataformas Uber Juntos, que substituiu o antigo UberPool, e Zumpy, cujo objetivo é facilitar a contratação de motorista profissional, com divisão entre os passageiros da remuneração por seus serviços.

20 O modelo de negócios das plataformas de intermediação de caronas parece não estar ainda consolidado. Waze Carpool ainda não cobra pelo serviço prestado. Segundo matéria de imprensa (SOPRANA, 2018), a empresa informa que o “modelo de monetização ainda não está desenhado e depende da escala.”. Já BlaBlaCar suspendeu temporariamente a cobrança mensal de seu serviço de intermediação dos usuários, talvez pela entrada do Waze Carpool no mercado. Os termos e condições mencionam que os passageiros deveriam pagar assinatura mensal (cujo valor mais recente foi de $\mathrm{R}$ \$ 9,90), com renovação automática, para ter acesso à plataforma, ou fariam um cadastro para ter acesso por uma semana, e motoristas não pagariam pela divulgação das viagens (BLABLACAR, 2018a). Quanto ao compartilhamento das despesas de viagem, cabe ao ofertante da carona definir seu valor, observados limites impostos pela plataforma para evitar a inclusão de remuneração disfarçada. Passageiros pagam em dinheiro ao motorista. Outra forma de financiamento da plataforma BlaBlaCar é o compartilhamento de dados dos usuários e a divulgação de publicidade. A empresa menciona expressamente como os dados são disponibilizados para seus parceiros (BLABLACAR, 2018b). 
aproximação se confunde com a atividade fim, que as plataformas se propõem a estimular. O Tinder, por exemplo, facilita o contato entre pessoas para fins de relacionamentos. Mas o simples fato de alguém se cadastrar na plataforma e utilizá-la para conhecer pessoas não lhe dá garantias de que irá, de fato, encontrar alguém, tampouco de que encontros presenciais ocorrerão após contato virtual, ou de que encontros presenciais serão bem-sucedidos, conduzindo, ao final, a relacionamentos firmes. O Tinder não “realiza” encontros ou relacionamentos; limita-se a criar ambiente virtual voltado a facilitá-los.

O funcionamento de plataformas desse tipo (de aproximação) em regra não depende de outorga ou licença administrativa. Trata-se de atividade livre, protegida pelo princípio constitucional da livre iniciativa (art. 170, caput, da Constituição) (BRASIL, 1988). As plataformas para caronas também não estão vinculadas às normas e competências das autoridades administrativas incumbidas da regulação dos transportes públicos ou privados, pois não prestam esse tipo de serviço.

O desenvolvimento dos meios de aproximação entre cidadãos, propiciado pela tecnologia digital, tem potencial para alterar a antiga organização econômica dos transportes. Os aplicativos viabilizam a economia compartilhada, fazendo com que associações específicas entre cidadãos se multipliquem e se tornem alternativa à mobilidade em geral. Mas nem por isso o Estado pode, para preservar os negócios dos transportadores profissionais, em regime público ou privado, cercear as associações específicas entre cidadãos, ou nelas interferir usando instrumentos regulatórios.

Por um lado, a Constituição o impede, pois garante as liberdades de locomoção e de associação dos cidadãos (art. $5^{\circ}$, caput e incisos XV e XVII) (BRASIL, 1988). Por outro, as competências regulatórias setoriais se exercem apenas sobre os agentes do setor para o qual foram instituídas por lei, não alcançando terceiros que desenvolvam atividades lícitas, e isso ainda que tais atividades repercutam sobre o setor regulado.

Postura estatal desse tipo seria também contrária aos objetivos da política nacional de mobilidade urbana, em favor da "melhoria nas condições urbanas da população no que se refere à acessibilidade e à mobilidade” e da promoção do “desenvolvimento sustentável com a mitigação dos custos ambientais e socioeconômicos dos deslocamentos de pessoas e cargas nas cidades” (art. $7^{\circ}$, III e IV, da Lei da Política Nacional de Mobilidade Urbana) ${ }^{21}$ (BRASIL, 2012). Na cidade de São Paulo,

21 Sobre a diminuição da emissão de "gases-estufa” com o compartilhamento de carro e sua contribuição para uma economia mais sustentável, confira-se o estudo Greenhouse Gas Emission Impacts of Carsharing in North America (MARTIN; SHAHEEN, 2011). 
exemplo de medida alinhada com tal objetivo é a proibição de, em certas vias, circularem carros particulares apenas com o condutor, sem passageiros ${ }^{22}$.

Vêm se multiplicando as iniciativas de incentivo público ao compartilhamento privado de veículos, com a consequente proibição do uso do poder regulatório do Estado para, em nome da proteção econômica dos serviços das empresas de transporte, impedir soluções compartilhadas, como as caronas.

No âmbito da União Europeia, por exemplo, plataformas de aproximação receberam proteção jurídica específica e expressa. A Diretiva 2000/31/CE do Parlamento Europeu e Conselho da União Europeia obriga os Estados-Membros da União Europeia a não criarem obstáculos artificiais ao funcionamento dessa solução, própria da "sociedade de informação”. O tom geral da diretiva é dado pelos arts. $4^{\circ}$ e $9^{\circ}$, que dizem respeito, respectivamente, ao “princípio de não autorização prévia” e ao "regime de contratos". Veja-se:

Art. $4^{\circ}$. [...] 1. Os Estados-Membros assegurarão que o exercício e a prossecução da actividade de prestador de serviços da sociedade da informação não podem estar sujeitas a autorização prévia ou a qualquer outro requisito de efeito equivalente.

$[\ldots]$

Art. $9^{\circ}$. [...] 1. Os Estados-Membros assegurarão que os seus sistemas legais permitam a celebração de contratos por meios eletrônicos. Os Estados-Membros assegurarão, nomeadamente, que o regime jurídico aplicável ao processo contratual não crie obstáculos à utilização de contratos celebrados por meios electrónicos, nem tenha por resultado a privação de efeitos legais ou de validade desses contratos, pelo facto de serem celebrados por meios electrónicos (PARLAMENTO EUROPEU E CONSELHO DA UNIÃO EUROPEIA, 2000).

Na Espanha, uma plataforma privada de caronas chegou a ser demandada judicialmente, sob a acusação de que suas atividades importariam violação às normas de transportes terrestres e concorrência desleal. O objetivo era sujeitar a plataforma aos requisitos e exigências previstos pela legislação para os serviços de transporte, submetendo-a, via Judiciário, à regulação estatal. A sentença declarou o pedido improcedente (ESPAÑA, 2017).

No Brasil, não existe lei nacional que confira, a qualquer autoridade administrativa reguladora dos transportes, competência para também regular as plataformas tecnológicas de aproximação entre cidadãos para fins de oferta de caronas. Aliás, independentemente da questão tecnológica, é preciso notar que a própria atividade de intermediação entre ofertante e tomador de carona é livre, não sujeita à autorização prévia ou à regulação administrativa.

Nesse aspecto, o setor de transporte se distingue claramente de outros setores, bem específicos, em que a atividade de intermediação entre agentes privados é ela própria regulada pela

22 Esse foi o caso do viaduto Doutor Plínio de Queiroz. Confira-se notícia veiculada pelo jornal O Estado de São Paulo (DIÓGENES, 2017). 
lei. Nesses setores específicos, muito naturalmente as plataformas tecnológicas de intermediação também estão sujeitas a regulação estatal.

Exemplos bem conhecidos são a XP (plataforma on-line registrada no Banco Central para negociar valores mobiliários e distribuir investimentos de outras instituições, tais como CDBs e LCI) e a Decolar (plataforma on-line registrada no Ministério do Turismo para comercializar produtos de viagem, tais como passagens aéreas e diárias em hotéis). Nesses casos, em função da própria natureza dessas atividades específicas de intermediação (intermediação de operações financeiras, no primeiro caso $^{23}$, intermediação de serviços turísticos, no segundo ${ }^{24}$ ), há lei impondo a regulação administrativa de modo expresso, independentemente do fato de serem ou não realizadas por plataforma digital.

A tecnologia permitiu a criação de novos e poderosos instrumentos de intermediação, inclusive nos setores bancários e de turismo. Ocorre que, nesses dois setores, diferentemente de outros (como o setor de transportes), a regulação legal e administrativa da atividade de intermediação precede o advento das inovações tecnológicas, e em princípio faz sentido que a regulação persista depois delas. Portanto, plataformas que fazem a intermediação nos setores bancários e de turismo são reguladas por autoridades administrativas não pelo fato de serem plataformas digitais, mas porque realizam atividades de intermediação que em si já eram - e ainda são - sujeitas à regulação administrativa, em virtude de lei expressa.

Mas, não pode existir regulação administrativa sobre atividades privadas sem lei que a preveja. Seria incorreto, portanto, comparar as plataformas de intermediação financeira ou de turismo com as plataformas de intermediação de caronas. No caso dessas últimas, não há previsão legal para sua submissão à regulação por autoridade pública. Não houve e não há lei que autorize a regulação administrativa de caronas, muito menos a regulação de sua intermediação pelos aplicativos. E são relevantes as razões para o Legislativo não editar lei com esse teor. De um lado, parece não haver necessidade de regulá-las - em regra, as atividades privadas dos cidadãos não são objeto de regulação estatal específica. De outro, porque eventual regulação restritiva, ao menos quanto às caronas, poderia violar os limites da intervenção estatal - a Constituição, como visto, confere especial proteção à liberdade de associação, o que inclui a associação pontual para fim específico, como a carona.

23 A Lei do Sistema Financeiro Nacional (Lei 4.595/1964) incluiu no conceito de instituições financeiras "as pessoas jurídicas públicas ou privadas, que tenham como atividade principal ou acessória a coleta, intermediação ou aplicação de recursos financeiros próprios ou de terceiros" (art. 17) e estabeleceu que elas só poderiam "funcionar no País mediante prévia autorização do Banco Central da República do Brasil ou decreto do Poder Executivo, quando forem estrangeiras” (art. 18) (BRASIL, 1964).

24 A Lei da Política Nacional do Turismo (Lei 11.771/2008), por sua vez, estabeleceu balizas à atividade de intermediação realizada por agências de turismo, limitando-a (art. 27 et seq.) (BRASIL, 2008). 
Mas essa discussão - a da necessidade ou possibilidade de, por meio de regulação, o Estado limitar, onerar ou coibir a expansão dos serviços de intermediação por aplicativo no setor de transportes, inclusive quanto às caronas - em pouco tempo pode estar superada. É compreensível que, sendo os aplicativos uma novidade, reguladores do setor de transportes tendam no primeiro momento a vê-los como ameaça, dado seu potencial para, em médio prazo, universalizar novas formas de relacionamento entre passageiros e transportadores, profissionais ou não. Caronas, por exemplo, podem se tornar alternativas relevantes em muitas situações, afetando as receitas do sistema de transporte público e, no limite, exigindo mais subsídios públicos ao sistema.

Alguns pesquisadores e reguladores começam a discutir a possível reforma do transporte de massa, hoje muito dependente dos serviços públicos de grandes estruturas e grandes empresas e, claro, com ineficiências a eliminar (por exemplo, ônibus circulando quase vazios nos trechos finais da linha ou em horários de menor demanda). Faz sentido, em princípio, para aumentar a eficiência, estimular a integração do sistema público com soluções privadas de transporte individual, inclusive não profissionais, como a carona ${ }^{25}$.

Em breve, discussão inversa da atual deverá ocupar as autoridades: como fomentar as caronas? A resposta provavelmente passará pelo fomento aos próprios aplicativos de intermediação, dada sua capacidade de multiplicar com rapidez tanto as oportunidades para ofertantes e tomadores, como a obtenção de informações úteis para planejar e gerenciar o sistema como um todo (informações agregadas sobre trajetos, destinos, horários, duração, perfil, etc.). Assim, outra agenda de pesquisa jurídica, complementar à desenvolvida no presente artigo, abre-se no campo dos transportes - não mais a agenda da regulação restritiva dos serviços de transporte e da concorrência, mas dos instrumentos jurídicos para o fomento à economia colaborativa em transporte.

Também alguns desafios regulatórios novos terão de ser encarados, com relação sobretudo aos aplicativos. Um deles é o da territorialidade, isto é, quanto à licitude da prestação de serviços de intermediação de transporte por plataformas hospedadas fora do Brasil. O problema não parece específico do setor, alcançando também operações financeiras, telecomunicações, educação, etc. Seu estudo está entre os desafios da citada agenda complementar.

25 Exemplo nessa linha é a pesquisa Mobilidade do Futuro: Um Modelo Disruptivo para São José dos Campos (BIDERMAN, 2019). 


\section{CONCLUSÃO}

Com o surgimento de aplicativos para a intermediação de caronas, elas começam a ser usadas em escala como solução alternativa de transporte, convivendo com os serviços de transporte tradicionais e gerando receios entre os prestadores e dúvidas jurídicas entre as autoridades. O presente artigo procurou enfrentar parte dessa agenda de debates, incluída entre os desafios propostos pela emergência da nova economia colaborativa.

São lícitas, no Brasil, a atividade de carona e a intermediação de carona via aplicativo. A carona é exemplo de associação lícita e específica entre cidadãos. Viagens por carona são ajustes para deslocamentos conjuntos, comunhão de esforços entre pessoas (envolvendo bens, recursos, atividades ou prestações) para a consecução de fim comum (deslocamentos para determinados locais ou regiões). A despeito de colaborações desse tipo não se estenderem por longos períodos, e de poderem assumir formas variadas, também possuem caráter associativo, nos termos do art. $5^{\circ}$, XVII, do texto constitucional. Além disso, a liberdade de locomoção também é protegida constitucionalmente (art. $\left.5^{\circ}, \mathrm{XV}\right)$.

O compartilhamento de custos entre condutores e caronistas não transforma a atividade de carona em prestação de serviço de transporte. Carona supõe identidade de interesses, tanto de quem dá como de quem toma: ambos têm efetiva necessidade ou desejo pessoal de se deslocar para destino comum. Não há prestação e contraprestação, mas concurso entre os envolvidos, que assumem o transporte como atividade conjunta, mesmo que cada envolvido participe com ações diferentes. Na forma do art. 736 do Código Civil, as caronas não se subordinam às normas do contrato de transporte.

A obtenção de simples benefício, mesmo econômico, pelos envolvidos na carona não é suficiente para caracterizá-la como atividade econômica. Conforme o art. 730 do Código Civil, o serviço de transporte, uma atividade econômica, supõe, por um lado, o transporte como ofício ou profissão, e, por outro, o objetivo lucrativo, evidenciado pelo pagamento de retribuição, remuneração em sentido próprio.

Caronas são meio de colaboração e associação específica entre cidadãos; nada têm a ver com prestação de serviço remunerado, público ou privado. Por isso, não pode o Estado coibi-las ou regulálas. Ademais, no regime legal vigente, o funcionamento de empresas que não realizam atividades de transporte, limitando-se a prestar serviços de aproximação entre cidadãos interessados em dar e tomar carona, não depende de outorga ou licença administrativa, nem está vinculado às normas e competências das autoridades administrativas incumbidas da regulação dos transportes públicos ou privados. 


\section{REFERÊNCIAS}

ACCIOLY, João Pedro. Liberdade de associação: trajetória histórica, Direito Comparado e âmbitos de proteção. Revista Brasileira de Estudos Constitucionais - RBEC, Belo Horizonte, ano 10, n. 36, set./dez. 2016.

BIDERMAN, Ciro (coord.). Mobilidade do Futuro: Um Modelo Disruptivo para São José dos Campos. Pesquisa. Fundação Getulio Vargas. Centro de Estudos de Política e Economia do Setor Público - CEPESP/FGV, previsão de conclusão: 2021, em andamento (2019). Disponível em: https://bit.ly/2mrn0gj. Acesso em: 20 set. 2019.

BLABLACAR. Política de Privacidade e de Proteção de Dados. 15 jul. 2018b. Disponível em: https://bit.ly/2m4hkc4. Acesso em: 20 set. 2019.

BLABLACAR. Termos e Condições. 15 jul. 2018a. Disponível em: https://bit.ly/2kIelpn. Acesso em: 20 set. 2019.

BRASIL. Constituição da República Federativa do Brasil de 1988. Diário Oficial da União, Brasília, DF, 5 de outubro de 1988. Disponível em: https://bit.ly/1bJYlGL. Acesso em: 31 maio 2019.

BRASIL. Lei N 10.406, de 10 de janeiro de 2002. Institui o Código Civil. Diário Oficial da União, Brasília, DF, 11 jan. 2002. Disponível em: https://bit.ly/1drzx5j. Acesso em: 31 maio 2019.

BRASIL. Lei Nº 11.771, de 17 de setembro de 2008. Dispõe sobre a Política Nacional de Turismo, define as atribuições do Governo Federal no planejamento, desenvolvimento e estímulo ao setor turístico; revoga a Lei no 6.505, de 13 de dezembro de 1977, o Decreto-Lei no 2.294, de 21 de novembro de 1986, e dispositivos da Lei no 8.181, de 28 de março de 1991; e dá outras providências. Diário Oficial da União, Brasília, DF, 18 set. 2008. Disponível em: https://bit.ly/2V0NXUn. Acesso em: 31 maio 2019.

BRASIL. Lei $N^{\circ}$ 12.587, de 3 de janeiro de 2012. Institui as diretrizes da Política Nacional de Mobilidade Urbana; revoga dispositivos dos Decretos-Leis nº 3.326, de 3 de junho de 1941, e 5.405, de 13 de abril de 1943, da Consolidação das Leis do Trabalho (CLT), aprovada pelo DecretoLei $n^{\circ} 5.452$, de $1^{\circ}$ de maio de 1943, e das Leis $n^{\circ}$ s 5.917, de 10 de setembro de 1973, e 6.261, de 14 de novembro de 1975; e dá outras providências. Diário Oficial da União, Brasília, DF, 4 jan. 2012. Disponível em: https://bit.ly/1gDQwjQ. Acesso em: 31 maio 2019.

BRASIL. Lei $\mathrm{N}^{\circ} 13.640$, de 26 de março de 2018. Altera a Lei $\mathrm{n}^{\circ} 12.587$, de 3 de janeiro de 2012, para regulamentar o transporte remunerado privado individual de passageiros. Diário Oficial da União, Brasília, DF, 27 mar. 2018. Disponível em: https://bit.ly/2LRjk3U. Acesso em: 31 maio 2019.

BRASIL. Lei No 4.595, de 31 de dezembro de 1964. Dispõe sobre a Política e as Instituições Monetárias, Bancárias e Creditícias, Cria o Conselho Monetário Nacional e dá outras providências. Diário Oficial da União, Brasília, DF, 31 dez. 1964, suplemento e retificado em 3 fev. 1965. Disponível em: https://bit.ly/2LHtO0P. Acesso em: 31 maio 2019. 
BRASIL. Lei No 9.503, de 23 de setembro de 1997. Institui o Código de Trânsito Brasileiro. Diário Oficial da União, Brasília, DF, 24 set. 1997, retificado em 25 set. 1997. Disponível em: https://bit.ly/1m5oosd. Acesso em: 31 maio 2019.

BRASIL. Superior Tribunal de Justiça. Súmula n. ${ }^{0} 145$. No transporte desinteressado, de simples cortesia, o transportador só será civilmente responsável por danos causados ao transportado quando incorrer em dolo ou culpa grave. Segunda Seção, j. 08 nov. 1995, DJ, 17 nov. 1995, p. 39295. Disponível em: https://bit.ly/30VbkCe. Acesso em: 31 maio 2019.

COELHO. Fabio Ulhoa. Curso de Direito Civil - Contratos. 7. ed. São Paulo: Saraiva, 2017.

DIÓGENES, Juliana. Gestão Doria vai multar carros em viaduto da 9 de Julho a partir do dia 23. O Estado de S. Paulo, São Paulo, 4 jan. 2017. Disponível em: https://bit.ly/2Z3ukwJ. Acesso em: 30 maio 2019.

ESPAÑA. Juzgado de lo Mercantil $n^{\circ} 02$ de Madrid. Sentencia no ${ }^{\circ}$ 30/2017 (Procedimiento Ordinario 343/2015). Demandante: Confederacion Española de Transporte en Autobus CONFEBUS-. Demandado: Comuto Iberia S.L. y Comuto S.A. Juez/MAGISTRADO: Andrés Sánchez Magro. Madrid, España, j. 2. feb. 2017. Disponível em: https://bit.ly/30YdAIP. Acesso em: 30 maio 2019.

LENOIR, René. Le phénomène associatif. Revue Projet, Paris, nº 107, jul./ago. 1976.

MARTIN, Elliot W.; SHAHEEN, Susan A. Greenhouse Gas Emission Impacts of Carsharing in North America. IEEE Transactions on Intelligent Transportation Systems, [s. l.], v. 12, n. 4, Dec. 2011. Disponível em: https://bit.ly/2HLFkca. Acesso em: 30 maio 2019.

MEIRELLES, Hely Lopes. Direito Administrativo Brasileiro. Atualização de Délcio Balestero Aleixo e José Emmanuel Burle Filho. 38. ed. São Paulo: Malheiros, 2012.

MENDES, Gilmar Ferreira; COELHO, Inocêncio Mártires; BRANCO, Paulo Gustavo Gonet. Curso de Direito Constitucional. 4. ed. São Paulo: Saraiva, 2009.

NEGRÃO, Theotonio; GOUVÊA, José Roberto F.; BONDIOLI, Luis Guilherme A. Código Civil e legislação civil em vigor. Colaboração de João Francisco Naves da Fonseca. 29. ed. São Paulo: Saraiva, 2010.

PARLAMENTO EUROPEU E CONSELHO DA UNIÃO EUROPEIA. Diretiva 2000/31/CE, de 8 de junho de 2000. Jornal Oficial, [s. l.], n. L 178, 17 jul. 2000, p. 1-16. Disponível em: https://bit.ly/2JGxL5i. Acesso em: 30 maio 2019.

ROBERT, Jacques. Droit de l'Homme et Libertés Fondamentales. 5. ed. Paris: Montchrestien, 1993.

SCHOR, Juliet. Debatendo a Economia de Compartilhamento. In: ZANATTA, Rafael A. F.; PAULA, Pedro C. B. de; KIRA, Beatriz (org.). Economias do Compartilhamento e o Direito. Curitiba: Juruá Editora, 2017.

SILVA, José Afonso da. Comentário Contextual à Constituição. São Paulo: Malheiros, 2005. 
SILVA, Virgílio Afonso da. Princípios Fundamentais do Direito Constitucional. São Paulo: Saraiva, 2009.

\section{SIQUEIRA NETO, José Francisco; MENEZES, D. F. N. Ensaios de Economia Criativa e}

Colaborativa e sua Regulação. Belo Horizonte: Arraes, 2017.

SOPRANA, Paula. Waze lança serviço de carona no Brasil com preço máximo de R\$25. Folha de São Paulo, São Paulo, 21 ago. 2018. Tecnologia. Disponível em: https://bit.ly/2kKVYAc. Acesso em: 20 set. 2019.

\section{Carlos Ari Sundfeld}

Professor Titular na FGV Direito SP. Doutor e Mestre em Direito pela PUC/SP. Presidente da Sociedade Brasileira de Direito Público - SBDP. E-mail: carlos@sundfeld.adv.br

\section{André Rosilho}

Professor na FGV Direito SP. Doutor em Direito pela USP. Mestre em Direito pela FGV Direito SP. Coordenador do Observatório do TCU da FGV Direito SP e da Sociedade Brasileira de Direito Público - SBDP. E-mail: andre.rosilho@fgv.br 